\title{
Determination of Urban Sprawl Effects on Farmlands Value Using
} GIS

\section{Abstract}

This paper presents to determine urban sprawl boundaries and the factors of affecting farmland value in urban sprawl. Urban sprawl index is calculated to identify its boundaries and Analytic Hierarchic Process Method is used for determined to weight for the factors. By using these weights in the Geographic Information System (GIS) technology, the value map is created. We illustrate that the farmlands in urban sprawls lost their properties and transformed into urban lands. The analyses revealed that farm criteria have no effect on the lands in urban sprawl. Both urban and rural solutions should be improved in order to prevent the abuse of fertile farmlands that occurred as a result of urban sprawl.

\section{INTRODUCTION}

In all the sectors that form the basis of economy, the most important capital required to carry out the activities is land, but its way of usage, quality and description differ according to sectors. The land which is also an important means of investment
Keywords: Farmland, urban sprawl, AHP, GIS

*Assist. Prof. Dr. in Agricultural Economics Department at Selcuk University, Konya, Turkey ORCID

Email: zkarakayaci@gmail.com (Corresponding author)

**Assoc. Prof. Dr. in City and Regional Planning Department at Konya Technical University, Konya, Turkey ORCID Email: okarakayaci@ktun.edu.tr 
is described as farmland in rural areas and named as plot by taking another dimension in urban areas. On the other hand, with the effect of population increase, technological developments, change in customer demands and change in supply accordingly, socio-economic factors, development policies and many other factors; a hinterland has emerged which has characteristics different from the term farmland and plot between urban and rural area and it was defined as urban sprawl.

Showing differences of the concrete variables that determine to the hinterland in the context of the physical conditions of the region and the space usage habits leads tospecific difficulties in definition of urban sprawl (Angel, Parent, \& Civco, 2007). Although there are specific differences in the definition of term (Bhatta, 2010), there is an agreement that it displays an unplanned and disorganized growth characteristics and resources are used inefficiently (Bhatta, 2010; Hasse \& Lathrop, 2003; Pucher, Peng, Mittal, Zhu, \& Korattyswaroopam, 2007). Although there are various studies on urban sprawl, most of these studies assess urban sprawl in the sense of urban area. Moreover, there are different views on whether urban sprawl is the reason or result of land utilization, whether it is the development process of land or a model of land utilization (Galster et al., 2001). These debates have led to the need of study about urban sprawl especially in the last thirty years.

The lands of urban sprawl which are defined as lands that have lost their rural characteristics and yet cannot be defined as urban include specific uncertainties results in various problems such as unplanned urban growth and use of non-agricultural purpose. This problematic is admitted as the main reason for the uncertainty of the real estate valuation in the urban sprawl.

Methods of assessment differ according to the characteristics of premises (Ventalo \& Williams, 2001), ambiguities in the term of urban sprawl are effective in assessment activities. As a result of this, value differences occur in the process of transformation of farmland in urban sprawls which are under the pressure of urban growth into lands by losing their agricultural characteristic. The reason of this difference is that every assessment has different qualities and is influenced by different factors. In this context, there are important ambiguities about which factors affect the valuation of the land and which method should be used to valuate it that has lost their agricultural characteristics on urban sprawls and has not gained the characteristics of urban land.

The main objective of this study is to provide the solutions to this uncertainty about the valuation and the concept of urban sprawl. In this context, it was aimed to determine the boundaries of the 
urban sprawl in the study area, to identify the factors affecting the value of urban sprawl and to appraise the value of urban sprawl by using these factors.

\section{LAND USE CHANGE AND URBAN SPRAWL}

Practices of public policies which support industrial and business development close to highway depending on dwelling policies revealed sprawl which is a new phenomenon of urbanization (Polidoro, de Lollo, \& Barros, 2011). Urbanized areas which have sprawled towards outskirts rapidly with the aim of dwelling, industry and trade in USA towards the end of 1950's resulted in occupation of forests. This uncontrolled urbanization model was called urban sprawl (Bhatta, 2010). These areas can be deprived of infrastructure services, basic facilities such as health, education (Sudhira \& Ramachandra, 2007). After 1960's urban growth and urban sprawl are regarded as an important problem in many cities throughout the world and especially in metropolitan cities (Mills, 2003; Zhao, 2011).

Increase of demand for settlement area with the increase of population density in city center requires expansion beyond city boundaries in the sense of settlement (Cavailhès \& Wavresky, 2003). Expansion of urban areas caused decrease of first-class farmlands around various big cities (Livanis, Moss, Breneman, \& Nehring, 2006). Increasing the demand of farmlands for urban use has caused over time increasing the value of farmlands especially in areas of rapid urban growth (Coisnon, Oueslati, \& Salanié, 2014a; Livanis et al., 2006).

As the non-agricultural use of farmlands increase, it is observed that producers accept conversion of farmland on the grounds that opportunity cost is higher and they give up agricultural production (Adrian \& Cannon, 1992). Rent obtained in urban area being higher and risk being less than agricultural income is regarded as one of the reasons of expansion of cities towards farmland (Doğru, 2002). In spite of this, it is legally compulsory to protect farmland and use according to natural characteristics according to Law No. 5403 on Soil Preservation and Land Utilization in Turkey. However in Turkey, non-agricultural use of farmland through conversion of farmland into plots by making it zoned for housing within the scope of urban development is regarded as one of the most important problems. Within this scope, approaches about assessment of urban sprawl which are regarded as a process before misuse of farmlands is an issue which requires discussion in the sense of controlled development of this process.

(Oueslati, Alvanides, \& Garrod, 2015) emphasized the importance of agricultural productivity along the expansion boundaries of 
urban areas. As a result of analyses, coefficient of agricultural rent was found to be quite high contrary to previous studies. This case can be interpreted as that agricultural productivity is a real hindrance for urban sprawl in Europe. It is stated that agriculture is quite intensive on the city boundaries of Europe and there is high yield-profit relation. On the contrary to this situation, regardless of the efficiency of agriculture in Turkey, since urban rent is higher than agricultural rent fertile farmlands are opened to misuse such as urban sprawl.

\section{METHODOLOGY}

\section{Study Area}

This study was carried out in Konya province located in the Middle Anatolian Region of Turkey. The area of the city is the largest city of Turkey is $38.250 \mathrm{~km}^{2}$. Rural area constitutes an important part of the provincial area. The population of the province is 2.079 .225 with an annual $13 \%$ growth rate where $76 \%$ population lives in urban area (Turkstat, 2014). Urban population in Konya is growing rapidly because of the migration from rural area to urban area.

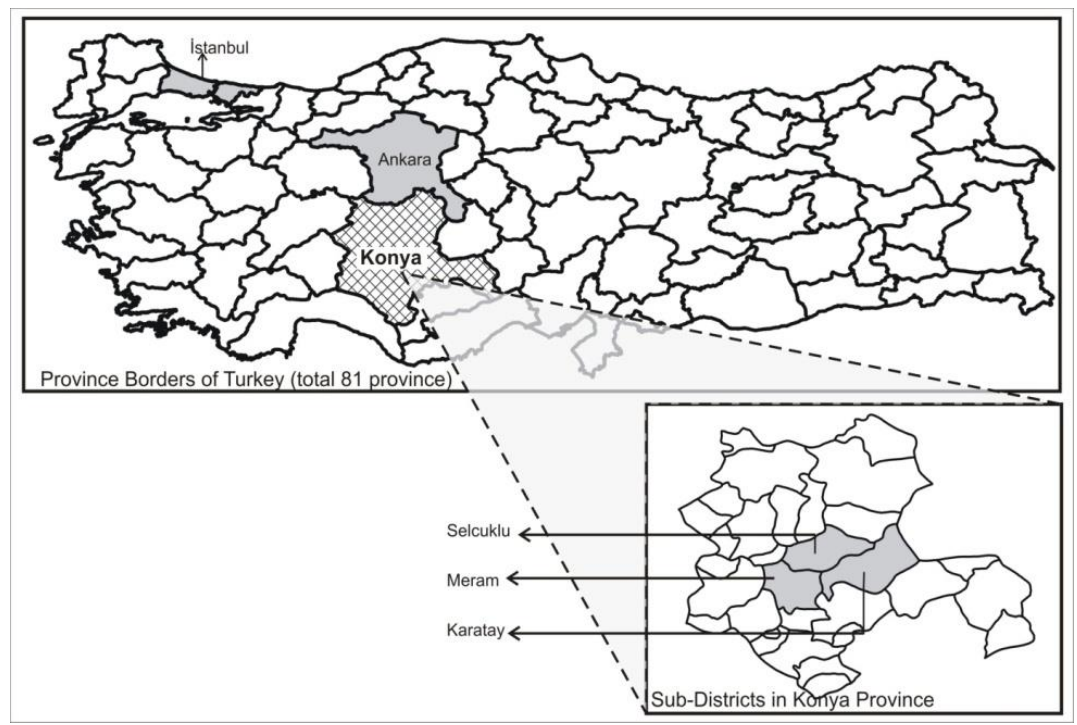

Figure 1. The location of study area within Turkey and Konya province
Konya consists of three sub-districts: Selcuklu, Meram and Karatay. These sub-districts divided into 264 quarters: 76 in Selcuklu, 103 in Meram, 85 quarters in Karatay. These quarters are spatial scale/units for this study. The impact of urbanization pressure on the farmland in the spatial units is one of the most important causes of urban sprawl.In Figure 2, the evaluations covering 9 different regions within Konya urban land not only demonstrate the pressure of urbanization on farmlands but also provide hints about the spatial, social and economic structure of the research region. 


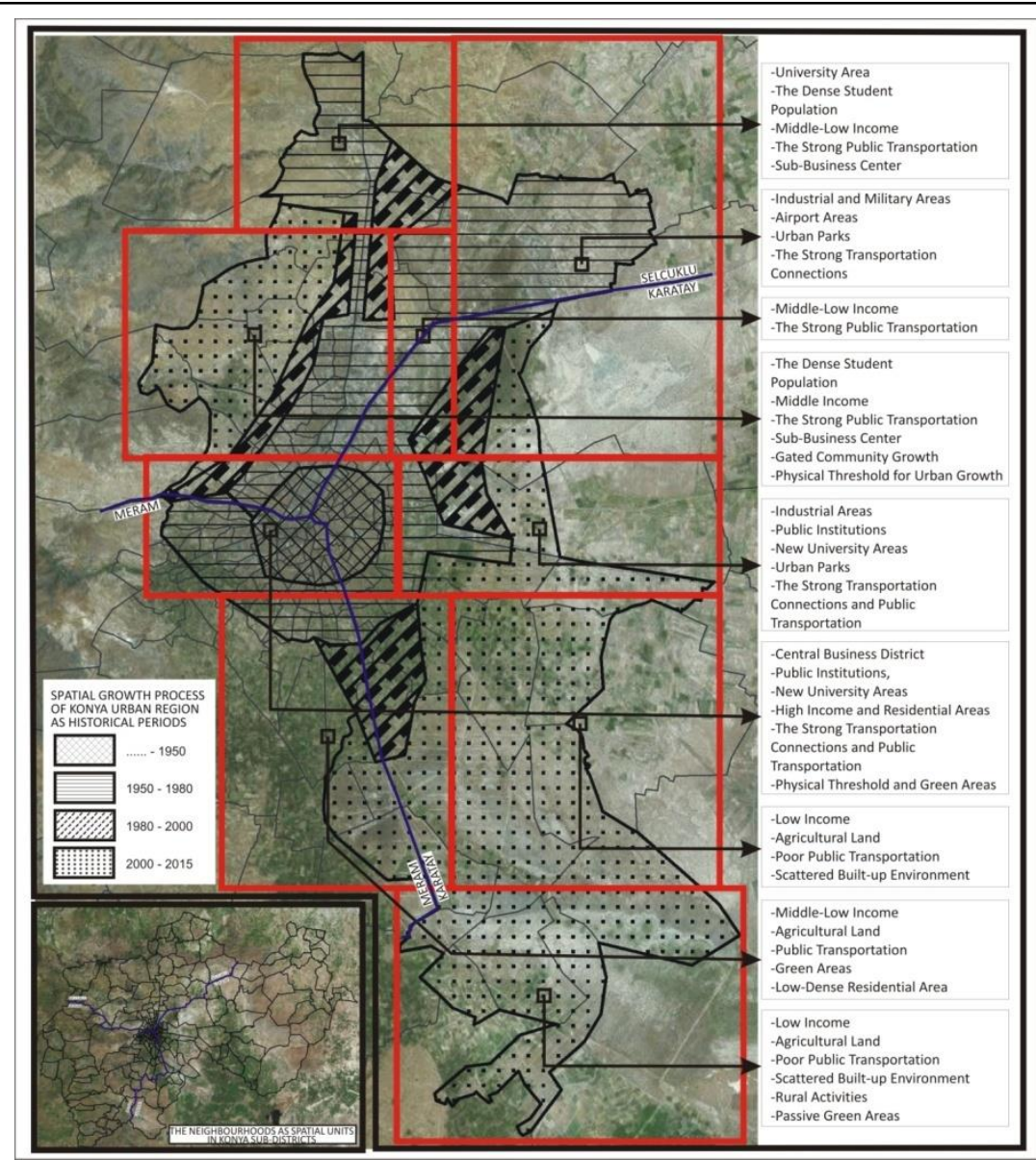

\section{Hypotheses}

This research has been built upon three key hypotheses: identifying sprawl areas in urban lands, factors effective on the land/area value in sprawl areas and the impacts of such factors on land/area value.

Within this framework the primary problem is detecting sprawl areas to utilize as research area. In studies aimed to detect sprawl areas, there is a tendency to identify sprawl areas via using weights obtained through employing various mathematical and statistical methods for measuring sprawls (Reid Ewing, Pendall, \& Chen, 2002; Hasse \& Lathrop, 2003; Terzi, 2010). Nonetheless the key problem here is not detecting sprawl areas via statistical and mathematical methods, but rather identifying the components showing the sprawl. Within this framework, in relevant literature there are vital discussions related to the types of components towards detecting sprawl areas. These discussions underline that sprawl areas cannot only be defined with respect to density criteria but accessibility, proximity, ambiguity of economic activities, lack of a definite urban/rural character and similar uncertainties in the types of land use were the basic elements (P. Torrens, 2008; $\mathrm{Wu}, 2006)$. Within this framework the foremost priority of current research is, in line with such discussions,
Figure 2. Spatial growth process of Konya Urban Region and its sociospatial characteristics 
testing the hypothesis towards detecting sprawl areas in Konya urban area.

Hypothesis 1. In addition to being low-density regions, sprawl areas are also characterized as the undefined lands with limited accessibility, away from urban and rural centers and lacking a diversification of land-use types.

There are various studies related to detecting the prices of land/area in sprawl areas; however nominal valuation method puts forth the potentials of land/area with respect to the factors affecting the value. Particularly towards the aim of defining spatial qualities of quarters, the application of GIS method facilitated the practicability of nominal valuation method in spatial scale. For instance, in terms of land use in urban sprawls, (R. Ready \& Abdalla, 2003), by employing GIS technology and hedonic price model, measured the impacts of spatial amenities and land use in the assessment of lands used as residential areas. Nominal value maps that shall be created by detecting via GIS analyses the potentials of spatial units are beyond an approach based on mathematical analyses but focused on the characteristic structure of the region. Therefore, the second hypothesis of this research has been identified within this framework.

Hypothesis 2. Although Nominal value explains the factors effective on the land/area values, the characteristic structure of the region is even more determinant in the identification of the weights of these factors.

As demonstrated in relevant literature, the indefinite spatial and functional structure of sprawl areas is the main causes of the factors impacting land/area value. The facts that these areas are exposed to pressures from both rural activities and urban activities, unproductive use of lands (Bhatta, 2010; Pucher et al., 2007), loss of green lands, deterioration in habitats, weakening of accessibility and similar negative urban problems and it also shows that within the scope of economical and spatial needs they may work as reservation lands for rural and urban areas. Therefore the correct identification of the factors impacting the value of sprawl areas in each region may demonstrate by what type of land use sprawl areas are pressured. To put this differently, the factors impacting land/area value in sprawl areas are concurrently the features prioritized in the urban-rural use of sprawl areas. Within this framework, the last hypothesis has been built upon sprawl areas and spatial and functional features of the factors affecting land/area value.

Hypothesis 3. Sprawl areas can not only stand as farm-activity focused regions with relation to the spatial and relational features of the region but they may also be reserve areas for urban 
expansion. Therefore the factors that leave an effect on the land/area value in sprawls are concurrently the factors providing hints on the spatial and relational use of sprawl region.

\section{Variables and Data Collection Procedures}

In current research, data collection procedure was implemented on the basis of two key stages. In the first stage, for the aim of defining spatial units that would constitute the scope of research, the variables to identify urban sprawl in Konya urban area were procured. In the second stage data related to the factors affecting land/area value were collected. Collected data were compiled on the scale of quarter, which is recognized as the smallest local administrative units in Turkey.

\section{Variables to determine sprawl areas}

In determining variables related to determining sprawl areas, theoretical arguments have been the determinants. Accordingly, in theoretical arguments in the definition of sprawl areas the most frequently employed factor appears to be 'density' (R Ewing \& Hamidi; Galster et al., 2001; Hasse \& Lathrop, 2003; Jiang, Liu, Yuan, \& Zhang, 2007). In relevant studies it has been emphasized that low-density lands demonstrate sprawl properties (Reid Ewing et al., 2002; Galster et al., 2001). Indeed, urban sprawls are low-density formations created in urban peripheries. Likewise in order to measure sprawling (P. Torrens, 2008) evaluated the proximity factor to city center and education units and underlined the gravity of accessibility in terms of sprawl criteria. Additionally, the emergence of sprawl as a result of the market developed toward the use of lands stuck between urban and farm use may also related to people's preference for living in spacious houses, amenities like shopping centers and proximity to similar facilities $(\mathrm{Wu}, 2006)$. Within this context life quality is linked to the preference for high locations, the amenities and conveniences provided by the city. ( $\mathrm{Wu}, 2006)$ in his study emphasized the significance of amenities in urban development models and reported that amenities play critical role in the selection of residential areas. The solidness of buildings' physical structures and number of floors, avoiding solid-fuel use to protect the environment and proximity to recreational lands are just a few of the amenities that play determinant role in the life quality of any city, thus these factors are also likely to play role in the detection of sprawl areas. Regardingly, the existence of suitable lands encompassing several amenities for land/area stock and enabling new structuring can also emerge as an acceptable factor in the definition of sprawl areas. Within this framework in order to measure the effect of urban sprawl on fragile natural resources 
(Hasse \& Lathrop, 2003) focused on the benefits of structured lands.

Determining the Factors Effective on the Value of Urban Sprawl

Physical factors like soil fertility, shape of land, land use, great soil group, land use capability class, elevation, aspect and crop rotation system have been taken into consideration to distinguish the transformed lands in urban fringes from farmlands because these factors are the criteria directly affecting the value of farmlands (Awasthi, 2009; Bellver \& Mellado, 2005; Karakayacl, 2018).

Distance to city center, rural center, highway and public lands were taken into evaluation since they are the kind of factors significantly affecting both farmlands as well land value. (Cavailhès \& Wavresky, 2003) reported that the relation between the value of farmlands in city peripheries and the distance to city center bears importance in terms of farm use as well as residential use. The writers also emphasized that the tendency to live in city peripheries for the sake of natural panorama, better life quality and physical surrounding and lower population triggered a rise for the demands toward sprawl areas. Besides, infrastructure amenities, structural density, presence of recreational lands and less commuting time are the top factors distinguishing areas and urban fringes from farmlands. Although the effect of environmental pollution differs for farmlands and areas, it is still a pivotal factor for both.

As frequently mentioned in relevant literature the most visible quality of urban sprawl is low-density population which inevitably leaves an effect on the land value. Demographic structure and income level of population bear critical importance in the demand for urban sprawl lands. In a number of researches conducted in Sofia by (Hirt, 2007; Slaev \& Nikiforov, 2013) it has been reported that in urban sprawl the income and education level of the population is higher. In contrast to this finding, in Konya urban sprawl constituting the scope of present study, the population living in sprawl areas has lower income level compared to the population in city center as manifested by compiled data. In order to demonstrate the causes of this divergence, factors such as demographic and cultural structure of the population and household income level have also been assessed.

Since urban sprawl cannot possibly make use of all the amenities of the city life, the presence of service units such as education and health as well the availability of residential zones has been considered as factors affecting the value of land. In addition, one of the reasons why people prefer to live in urban sprawl is that 
they favor to move away from stressful city life and live in a peaceful setting (Churchman, 1999), hence crime factor is another criterion that was considered.

In urban sprawl one of the most effective reasons causing the transformation of the lands from farm use to urban use is that the rent to receive from land use is higher than farm use (Adrian \& Cannon, 1992; Doğru, 2002), hence urban and farm income factors are other criteria that were taken into consideration. While tax applies to areas (residential), farmlands are exempt from property tax. Since it is an important factor distinguishing the residential area and farmland, it was also taken into account.

Since in farmlands there are different relations such as sharecropping and tenancy, the status of ownership bears utmost significance in order for the farmland to be sold. Considering that in urban sprawl constituting the scope of present research similar conditions might arise, the factor related to ownership status has been taken into consideration. In addition, since in farmlands it is likely to see pastures, forestry, conservation area etc. legal limits have been considered as another factor. Zoning status is vitally important in detecting urban sprawl and setting forth farmlandresidential area distinction. In order for any farmland to receive the status of residential area it requires a completed construction plan which significantly boosts the value of any land. Hence zoning status factor bears great share in the assessment of data provided in current research. In the light of all the assessments listed above, 21 variables were detected to identify sprawl areas in Konya research land and the factors affecting land/area values in urban fringes have been analyzed with respect to five criteria as physical, social, economic, environmental and legal. Since urban sprawl possess neither farmland nor urban land quality, in the detection of such factors, the kind of factors affecting the value of both farmlands and urban lands have been accepted as determinants. In this direction, the variables, the types and qualities of variables and the methods to collect these variables are as demonstrated in Table 1 and 2. 
Table 1. The variables using for determining of urban sprawl by quarter

\begin{tabular}{|c|c|c|c|}
\hline Variables & $\begin{array}{l}\text { The type } \\
\text { of data }\end{array}$ & Data & Sources \\
\hline $\begin{array}{l}\text { Population } \\
\text { Density }\end{array}$ & $\begin{array}{l}\text { Person } \\
\text { per } \\
\text { hectare }\end{array}$ & Quarter population / Quarter size & $\begin{array}{l}\text { Database of the } \\
\text { Municipality of } \\
\text { Konya }\end{array}$ \\
\hline $\begin{array}{l}\text { Accessibility } \\
\text { Time }\end{array}$ & Minute & $\begin{array}{l}\text { Time of arrival averagely to Centre of } \\
\text { quarter from centre of urban by public } \\
\text { transport }\end{array}$ & $\begin{array}{l}\text { Observation } \\
\text { and Assocation } \\
\text { of Public } \\
\text { Transport }\end{array}$ \\
\hline $\begin{array}{l}\text { Proximity to } \\
\text { Centre of City }\end{array}$ & kilometer & $\begin{array}{l}\text { Distance crow flies to Centre of quarter } \\
\text { from centre of urban }\end{array}$ & Map \\
\hline $\begin{array}{l}\text { Accessibility to } \\
\text { Education Area }\end{array}$ & Dummy & $\begin{array}{l}\text { The walking of distance is maximum } \\
500 \text { meter for primary school }\end{array}$ & $\begin{array}{l}\text { Database of the } \\
\text { Municipality of } \\
\text { Konya }\end{array}$ \\
\hline $\begin{array}{l}\text { Physical Quality } \\
\text { Analysis of } \\
\text { Buildings }\end{array}$ & Number & $\begin{array}{l}\text { Building with wreck } \\
\text { Building with structural deterioration } \\
\text { Building with high of structural quality }\end{array}$ & $\begin{array}{l}\text { Database of the } \\
\text { Municipality of } \\
\text { Konya }\end{array}$ \\
\hline $\begin{array}{l}\text { The using status } \\
\text { of building }\end{array}$ & Per cent & The used buildings/total buildings & $\begin{array}{l}\text { Database of the } \\
\text { Municipality of } \\
\text { Konya }\end{array}$ \\
\hline $\begin{array}{l}\text { Residential } \\
\text { housing }\end{array}$ & Number & Buildings used for accommodation & $\begin{array}{l}\text { Database of the } \\
\text { Municipality of } \\
\text { Konya }\end{array}$ \\
\hline $\begin{array}{l}\text { Building with } \\
\text { natural gas }\end{array}$ & Per cent & $\begin{array}{l}\text { Building with natural gas for energy } \\
\text { needs/ total buildings }\end{array}$ & $\begin{array}{l}\text { Database of the } \\
\text { Municipality of } \\
\text { Konya }\end{array}$ \\
\hline $\begin{array}{l}\text { Building with } \\
\text { solid fuel }\end{array}$ & Per cent & $\begin{array}{l}\text { Building with solid fuel for energy } \\
\text { needs/ total buildings }\end{array}$ & $\begin{array}{l}\text { Database of the } \\
\text { Municipality of } \\
\text { Konya }\end{array}$ \\
\hline $\begin{array}{l}\text { Analysis for } \\
\text { height of } \\
\text { buildings }\end{array}$ & Per cent & $\begin{array}{l}\text { Building with low-floor/total buildings } \\
\text { Building with middle-floor/ total } \\
\text { buildings } \\
\text { Building with high-floor/ total buildings }\end{array}$ & $\begin{array}{l}\text { Database of the } \\
\text { Municipality of } \\
\text { Konya }\end{array}$ \\
\hline $\begin{array}{l}\text { Analysis of green } \\
\text { areas }\end{array}$ & Per cent & $\begin{array}{l}\text { Size of green and play areas/total size of } \\
\text { quarter }\end{array}$ & $\begin{array}{l}\text { Database of the } \\
\text { Municipality of } \\
\text { Konya }\end{array}$ \\
\hline $\begin{array}{l}\text { Commercial } \\
\text { building }\end{array}$ & Number & Building used for trading & $\begin{array}{l}\text { Database of the } \\
\text { Municipality of } \\
\text { Konya }\end{array}$ \\
\hline $\begin{array}{l}\text { Manufacturing } \\
\text { building }\end{array}$ & Number & Building used for industrial activities & $\begin{array}{l}\text { Database of the } \\
\text { Municipality of } \\
\text { Konya }\end{array}$ \\
\hline $\begin{array}{l}\text { Number of } \\
\text { Households }\end{array}$ & Number & $\begin{array}{l}\text { Population in the quarter/total building } \\
\text { in the quarter }\end{array}$ & $\begin{array}{l}\text { Database of the } \\
\text { Municipality of } \\
\text { Konya }\end{array}$ \\
\hline \multirow{2}{*}{$\begin{array}{l}\text { Density of } \\
\text { construction }\end{array}$} & \multirow[t]{2}{*}{ Number } & $\begin{array}{l}\text { Number of legal actual construction } \\
\text { within last year }\end{array}$ & $\begin{array}{l}\text { Database of the } \\
\text { Municipality of } \\
\text { Konya }\end{array}$ \\
\hline & & $\begin{array}{l}\text { Number of non-legal actual construction } \\
\text { within last year }\end{array}$ & $\begin{array}{l}\text { Database of the } \\
\text { Municipality of } \\
\text { Konya }\end{array}$ \\
\hline Total building & Number & $\begin{array}{l}\text { Building used for various activities in } \\
\text { the quarter }\end{array}$ & $\begin{array}{l}\text { Database of the } \\
\text { Municipality of } \\
\text { Konya }\end{array}$ \\
\hline
\end{tabular}

Table 2. The factors affecting value of urban sprawl

\begin{tabular}{l|l}
\hline Physical Factors & Environmental Factors \\
\hline Soil Fertility & Proximity to Rural Settlement \\
Shape of Land & Proximity to City Center \\
Land Use & Distance from Highway \\
Great Soil Group & Structure Density \\
Land Use Capability Class & Distance from Various Public Spaces \\
Elevation & Recreational Area \\
Aspect & Infrastructure \\
Erosion Degree & Commuting Time \\
Crop Rotation System & Environmental Pollution \\
\hline Social Factors & Economic Factors \\
\hline Population Density & Agricultural Rent \\
Demographic Structure of Population & Urban Rent \\
Residential Space & Tax \\
Per Capita Education Unit & Household Income Status \\
Per Capita Health Unit & Legal Factors \\
Crime Rate & Ownership Status \\
Cultural Community & Reconstruction \\
& Legal Restrict \\
\hline
\end{tabular}




\section{Methods and Analysis of Data}

The method process designated to test the hypotheses specified within the scope of research objective and to obtain research outcomes has been actualized in four main stages. Besides this method process offers a more systematic perspective that makes research findings and outcomes more comprehensible and detectable.

Accordingly, the key driving point has been detecting the urban sprawl in research area. In relevant literature the approaches towards detecting sprawl areas are mostly based on two main variables as population or construction density, but this approach fails to provide sufficient data on correct detection of sprawl lands. Driven from this perspective, as demonstrated in Table 1, next to density variable, 21 different variables have been used to detect sprawl areas. To the aim of making different variables more detectable and identify sprawl index, factor analysis has been conducted. According to the values obtained via summing up factor weights received for each single quarter, spatial units are categorized as areas with dense urbanization, urbanization, sprawls and areas bearing rural character. In that way in Konya region sprawl areas on quarter scale were detected. Thus, spatial units necessary for research area were defined and also Hypothesis 1 detected in relation to sprawl areas was tested.

In the second stage; factors affecting urban sprawl were designated. As listed in Table 2, these factors were detected within the main headings as physical factors, environmental factors, social factors, economical factors, legal factors. As mentioned in the literature, since the factors which have effect on the value of real estate do not have the effect at the same rate, weight coefficient should be determined for each factor. Mathematical and statistical methods can be used in order to measure factors' degree of effect on real estate. Weight coefficients are determined for each factor and mathematical or statistical models can be formed in this way. AHP method was used in weight determination stage for factors which affect the value.

To sum up via AHP method the weights of each factor have been detected within rural land, sprawl land and urban land. Since the research is based particularly on sprawl lands, AHP weight indexes specific to sprawl land were accounted. It was seen that 10 factors of which weight indexes are above $4 \%$ rendered greater effects on land/area value. Thus, variables of which effect on the value is below $4 \%$ were excluded from statistical analysis process. Within this framework, during the processes of nominal value map and statistical analyses, factors such as LUCC, proximity to city center, environmental pollution, household income level, 
education unit, urban rent, number of houses, zoning status, health unit, and infrastructure were manipulated as variables.

In order to obtain nominal value map detected within the scope of variables identified at the end of AHP method, scoring was conducted on the basis of the qualities of each quarter unit. This was the third stage of method process. In the process of obtaining nominal value map, spatial analysis menu of ArcGIS 9.1 package program was used. Following this stage, weights obtained in AHP analysis and values on nominal value were entered into ArcGIS database and a nominal value map was created on the basis of below-given formulation.

$\mathrm{NV}=\sum_{1}^{i}\left(\right.$ ifactor $_{\mathrm{s}} *$ if $\left._{\text {actor }} \mathrm{w}\right)$

(Formula 1)

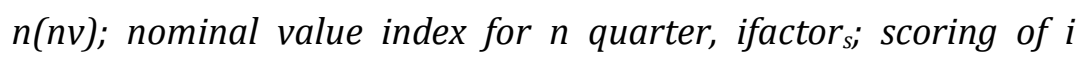
variable for $n$ quarter, ifactor $w_{w}$; weight value of $i$ variable for $n$ quarter

Consequently, via nominal valuation method average nominal values for each quarter in research area were detected. In this method, via functionalizing the factors effective on value, obtained coefficients can be exchanged into current value at any time. Thanks to value maps created with these coefficients, the values are safeguarded against any potential regional or national economic changes.

\section{RESULTS AND DISCUSSION}

\section{Sprawl Areas in Konya Urban Region}

Since the dimensions of urban sprawl differ from place to place, it is not possible to generate generalizable criteria to measure the degree of urban sprawl (Estiri, 2012). It is not easy to set a threshold in order to determine whether there is a sprawl or not certainly. Researchers generally determine this threshold according to their own assumptions (Bhatta, 2012). As stated in methodology section, in the detection of urban sprawl within the scope of current research the objective is to designate sprawl areas specific to 21 variables such as density, accessibility, proximity and land-use density and to test Hypothesis 1.

Urban sprawls are the areas stuck between rural land and urban land and their borders are not neatly specified. Therefore, in Konya city constituting the scope of this research, data were collected specific to 21 variables detected on the basis of quarter scale which is the smallest administrative unit. However, since analyses to conduct via 21 variables would give methodological errors, factor analysis was made to obtain smaller numbers of factors to represent the relations among these variables in the highest possible level and number ofvariables was reduced to 4 factors. 
According to the result of the analysis, total variance percentage of the 4 factors obtained was measured as $63.34 \%$. Four factors were renamed on the basis of the qualities of variables. Hence since factor 1 included physical variables such as density, accessibility and structure quality it was named as density and accessibility factor (F1). Since Factor 2 mostly demonstrated urban amenities and quality it was defined under the heading urban amenities (F2). Socio-economic factors such as commercial and industrial buildings, number of household were defined as Factor 3 (F3) and lastly factor 4 (F4) in which variables related to the speed of structuring were grouped is defined under the general heading structuring mobility.

In theoretical part, driven from the arguments on sprawl areas, instead of rise sprawl in variables such as density-accessibility and urban amenities urbanization tendency; household, industrial structures and increase in structuring speed are, rather than urbanization, demonstrated sprawl tendency, hence in Konya research area, sprawl index in quarter scale has been calculated as below.

$$
U S I_{n}=\left(F 3_{n}+F 4_{n}\right)-\left(F 1_{n}+F 2_{n}\right)
$$

(Formula 2)

$\mathrm{USI}_{\mathrm{n}}$ urban sprawl index for $\mathrm{n}$ quarter, $\mathrm{F} 1_{\mathrm{n}}$ factor weight of factor 1 for $n$ quarter, $F 2_{n}$ factor weight of factor 2 for $n$ quarter, $F 3_{n}$ factor weight of factor 3 for $n$ quarter, $\mathrm{F} 4_{\mathrm{n}}$ factor weight of factor 4 for n quarter.

At the end of conducted calculations index values obtained for each single quarter have been classified. The key reason behind this classification is to present the sprawl occurred as a result of the transfer of development due to rapid urbanization toward urban peripheries and rural lands. At the end of this classification quarter settlements of which index value is between -0.49 and +0.49 were recognized as urban sprawl. As shown in Figure 3, at the end of these evaluations, while in Konya case 39 quarters demonstrated dense urbanization characteristics, 55 quarters demonstrated urbanization characteristics and 42 quarters demonstrated rural land characteristics, 76 quarters were in village status and 52 quarters were seen to have sprawl tendency. In the next stages, sample area of present research contained 52 quarters bearing sprawl characteristics.

Low-density housing is among the primary indicators of sprawl tendency (Reid Ewing \& Hamidi, 2014). As also argued by (Churchman, 1999), driven from the hypothesis that high density settlements lead to sprawl, in current research population and housing densities in city center and urban peripheries were taken into account. (Churchman, 1999) claimed that in high-density cities people tend to complain about the crowd and congestion 
and that sprawl started a result of this tendency to move away from this density. Indeed, as seen in case study Konya, parallel to the population boom witnessed in due course, a corresponding rise in demand for housing led to congestion in city center and consequently urbanization shifted towards city periphery. Likewise, (Hasse \& Lathrop, 2003) detected that density shifted from old city centers and rural lands to the new settlements. This deduction validates Hypothesis 1 specified within the scope of current study. That is because socio-economic factors and life styles are a few of the factors behind low-density areas.

In contrast to urban sprawls city centers are the areas in which economic and social activities are at their peak. Noting the fact that for employment and social activities people need to use city center, it is seen that proximity to city center is a vital factor in determining sprawl area, thus accessibility matters vitally in sprawls as also emphasized by (P. M. Torrens \& Alberti, 2000). It is also known that since urban sprawls are away from city centers, they accelerate commuting time and costs. The rise in the distance toward city sprawls not only increases transportation costs but it also decreases the use of public transportation and increases the dependency on private vehicles (Song \& Zenou, 2006).

Under the factor of constructing mobility the number of constructions built in the last year, number of unlicensed buildings and licensed buildings were counted. Since urban sprawls are the areas in which new constructions are intensely observed these criteria play critical role in the designation of urban sprawl borders. In particular, the frequency of unlicensed structures in the urban sprawls detected upon analysis verifies that the results of this analysis are valid. That is because urban sprawl may be the areas with no or limited infrastructure amenities and zoning plan has not yet been approved by concerned municipalities. Therefore, despite the absence of required licenses for construction the erection of new buildings is the most vital indicator of urban sprawling. Indeed, farmlands subjected to urban sprawling can gain land characteristics only after being considered as a zoning plan and benefit from urbanization amenities. In Greece-based study conducted by (Polyzos, Minetos, \& Niavis, 2013) the size of urban sprawl is calculated via rationing the constructing taking place outside the approved city by the ratio of total constructing and this is also supportive of the thesis stated above. If the opposite is valid, since in sprawl areas new construction plans are prepared, it is possible that high-rise and high-quality buildings shall multiply in significant numbers. 
To sum up it has been concluded in this research that urban sprawling speeds up the transformation process occurred in land use. It is seen that in research area transformation from rural land to urban land takes place rapidly. Urban sprawl affects farmlands in terms of both quantity and fertility (Adrian \& Cannon, 1992). In a research conducted by (Akseki \& Meşhur, 2013) as a consequence of urban sprawl witnessed for the last 50 years in Konya, 12.607 hectare $1^{\text {st }}$ class, 2.393 hectare $2^{\text {nd }}$ class, 55 hectare $3^{\text {rd }}$ class and 2.574 hectare $4^{\text {th }}$ class farmland were opened to constructing. In present study it was detected that $85 \%$ of the land designated as urban sprawl were prime fertile lands for farming. Likewise, (Hasse \& Lathrop, 2003) asserted that the loss of prime farmlands is, in contrast to non-prime farmlands, more vulnerable against urbanization. In line with his views (Delbecq, 2010) reported that sprawling is, on accounts of its low- density composition, the accelerated form of urban growth while on the other hand it is the destruction of farmlands. Figure 3 reveals that in Konya case urban sprawling expands towards the south. It is recognized that in southern Konya there are extremely fertile farmlands.

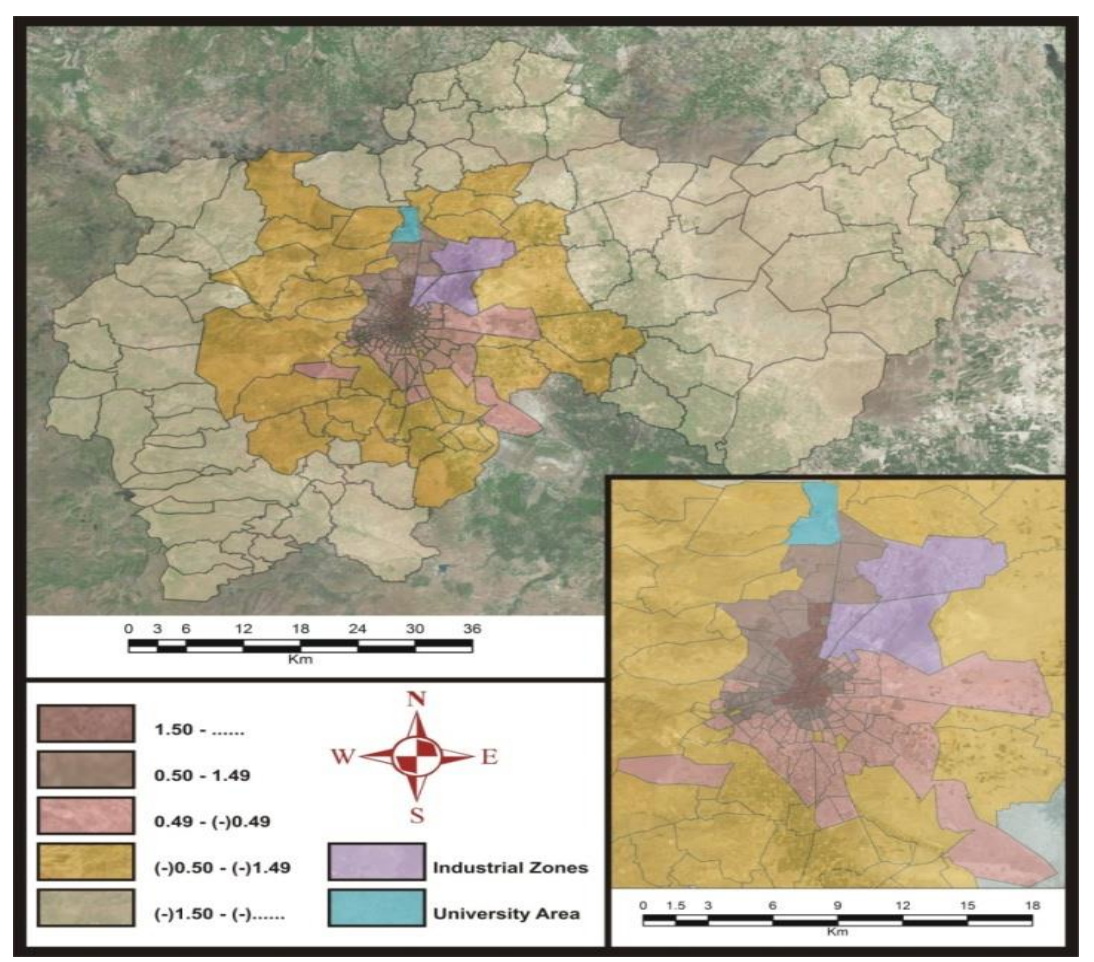

There are some reasons accounting for the transformation of these fertile farmlands into urban lands; in addition to the demands of people who felt sick of crowded cities and wanted to live city peripheries, population emigrated from villages to city center also favored to settle in areas closer to rural land can be recognized as the desire of rural population to benefit from the urban amenities while at the same time partially sustaining the
Figure 3. The characteristics of quarters in Konya according to Urban Sprawl Index 
land's farming activities. Using fertile farmlands to serve urban transformation stems from the failure in planning policies. (Slaev \& Nikiforov, 2013) also emphasized this factor and classified the role and functioning of planning among the factors affecting urban sprawling.

In urban sprawl constituting the scope of present study it is observed that farming activities are still practiced, though limited. As a result of the lower land rates in city peripheries the existence of payable housing means (Burton, 2000; Terzi, 2010) can be the reason why low- income rural population selected to settle in city sprawls. Also, the potential rise in land values as a result of future urban transformation in places nearby city (Cavailhes \& Thomas, 2011; Livanis et al., 2006) is another vital factor affecting the urban sprawling on fertile lands. It can even be argued that it is the most important factor in the assessment of urban sprawl phenomenon in terms of farming.

The Weights of the Factors Affecting Farmland/Urban Land Value in Sprawl Areas according to AHP Analysis

Urban sprawls are those between rural and urban land and whose boundaries were not determined exactly. There is no specific method is determination of the value of these areas, farmland and land valuation methods can be used. However, there are specific inconveniences in the use of these methods in the sense of land located in urban sprawl. Therefore, it is required to determine factors which affect the value correctly and detect valuation methods in areas at urban sprawl. For this aim, in the study factors affecting the value were weighted separately with AHP method in terms of farmland, urban sprawls and plot (table 3). Moreover, the structure of urban sprawl may differ according to the conditions of country or region. Therefore, general structure of Konya which is the study field was considered in weighting the factors.

Urban sprawls can be assessed as transition regions between farmland and plot (Thapa \& Murayama, 2008). Furthermore, to separate the farmland value within agricultural and urban components may lead to wrong results due to the farmlands close to the city center more sensitive to urban sprawl components (Livanis et al., 2006). Therefore, it is important for the whole three lands to determine weights and compare them in order to detect factors which affect urban sprawls. In actual fact, as a result of the analysis, it is seen that urban sprawls are similar to both farmlands and plots.

According to specified weights, for farmlands, physical factors with a ratio of $35.89 \%$, in city sprawls with a ratio of $36.13 \%$ and in areas with a ratio of $45.54 \%$ environmental factors are the most significant factors. With a ratio of $25.26 \%$ social factors, compared 
to other factors, play even greater role in urban sprawls. The population density in this group has importance due to the characteristics of urban sprawls but since housing area, the presence of educational and health units are the characteristics of being away from city center, these factors also carry value. Since farmlands are also production lands the factors in this group need not to be taken into account, but since in urban land these factors are already available, these factors do not carry as much value as the urban sprawls for the value of lands.

Although in Konya which is the study field, the effects of urbanization is observed depending on urban growth in urban sprawl, it is observed that agricultural production is done though partly because it is under the effect of urban land. Therefore, the structure of building which is like farmland and weight value of factors of land use capability capacity were higher in urban sprawls compared to plots. Another factor which makes land use capability factors important is that since land in I., II. and III class are convenient for agricultural production, it is wrong to misuse them for non-agricultural aims, it would be wrong for these areas to be located in urban sprawl and use them for urbanization aims.

It is observed that factor of distance to city center is important for all three types of estate. Since the lands has the characteristics of real estate, it was emphasized that they are important in the rate of $11,76 \%$. For agricultural areas, urban proximity means proximity to market which was important in the rate of $4.99 \%$. For urban sprawls factor of distance to city center has different meaning according to distance factor, farmland and plots. Since urban sprawls are the areas which is preferred by people who are fed up with the density of city (Churchman, 1999), factor of distance to city center is important.

It is seen that infrastructure factor has greater effect (7.54\%) on the value of land located in urban sprawls compared to other real estate. The reason of this is that urban sprawls are in transformation process from rural land to urban land. Since urban sprawls are in the characteristics of rural land, it is required primarily in the process of urbanization though it is devoid of infrastructure opportunities.

To sum up; according to the results of AHP analysis 9 criteria that have over $4 \%$ effect on land/area value such as land use capability class, proximity to city centre, infrastructure, environmental pollution, residential space, education unit, health unit, urban rent, household income have been the kind of variables employed in the detection of nominal value index and statistical analyses. 


\section{Nominal Value for Farmland/Urban Land in Sprawl Areas}

The foremost factor determining the value of any immovable property is its location (Din, Hoesli, \& Bender, 2001). According to the complex nature of land use pattern in urban sprawl, spatial parameters should be used in order to make measurement (Noor \& Rosni, 2013). The use of GIS in the spatial-parameters based analysis methods has recently become popular and as spatial parameters are also taken into consideration in the researches to detect land/area value it is seen that mostly GIS and hedonic price models are integrated (Livanis et al., 2006; R. C. Ready \& Abdalla, 2005). In the study of (Thapa \& Murayama, 2008) which was carried out by using integration of GIS and AHP techniques in order to determine suitable areas for agricultural production on city boundaries, they used spatial parameters such as land use, soil, water, road and market.

In the study which was carried out by (Sperandelli, Dupas, \& Dias Pons, 2013), it is emphasized that rural land and urban land boundaries cannot be separated clearly, although it is possible to determine that housing is intensive and determine city boundaries with road network and buildings when observed with aerial image. In order to determine these boundaries, the land was divided into three as urban land blank land, green land and occupied land and change of these lands according to years were analyzed with the help of GIS analysis. In the study it was concluded that blank land has decreased considerably and one of the reasons of this is urban sprawl.

The analysis of the values of farmlands closer to city center is more sensitive to urban sprawl components. Due to this effect separation of farmland value within farm and urban components may lead to obtaining misleading results (Livanis et al., 2006). Therefore in the production of value maps, in the previous section among the factors of which coefficient was above 0.04 and obtained via AHP method to designate the factors affecting the value of lands in urban sprawl, total 8 factors (proximity to city center, infrastructure amenities, environmental pollution, housing number, demand for educational and health units, urban rent and household income status) were utilized. 
Determination of Urban Sprawl Effects on Farmlands Value Using GIS

Table 3. The scoring variables affecting value for nominal value map

\begin{tabular}{|c|c|c|c|c|c|}
\hline Variable & & Score & & & Score \\
\hline \multirow{3}{*}{ LUCC } & $\begin{array}{l}\text { I-IV. } \\
\text { classlands }\end{array}$ & 10 & \multirow{3}{*}{$\begin{array}{l}\text { Education } \\
\text { unit }\end{array}$} & No need & 10 \\
\hline & $\begin{array}{l}\text { V-VI. } \\
\text { classlands }\end{array}$ & 5 & & Medium & 5 \\
\hline & $\begin{array}{l}\text { VII-VIII. } \\
\text { classlands }\end{array}$ & 1 & & Need & 1 \\
\hline \multirow{5}{*}{$\begin{array}{l}\text { Proximity to } \\
\text { city center }\end{array}$} & $1-2 \mathrm{~km}$ & 10 & \multirow{5}{*}{ Urban rent } & +-131 & 10 \\
\hline & $2.1-4 \mathrm{~km}$ & 7 & & $130-101$ & 7 \\
\hline & $4.1-6 \mathrm{~km}$ & 5 & & $100-71$ & 5 \\
\hline & $6.1-8 \mathrm{~km}$ & 3 & & $70-36$ & 3 \\
\hline & $8-+k m$ & 1 & & $35-0$ & 1 \\
\hline \multirow{5}{*}{$\begin{array}{l}\text { Environmental } \\
\text { pollution }\end{array}$} & $\begin{array}{lll}0 & - & 3 \\
\text { number/ha }\end{array}$ & 10 & $\begin{array}{c}\text { The number } \\
\text { of houses }\end{array}$ & $\begin{array}{c}+-32 \\
\text { number } \\
\text { /ha }\end{array}$ & 10 \\
\hline & $\begin{array}{ll}3.1 & - \\
\text { number /ha }\end{array}$ & 7 & & $\begin{array}{c}31-24 \\
\text { number } \\
\text { /ha }\end{array}$ & 7 \\
\hline & $\begin{array}{l}6.1-9 \\
\text { number /ha }\end{array}$ & 5 & & $\begin{array}{c}23-16 \\
\text { number } \\
/ \text { ha }\end{array}$ & 5 \\
\hline & $\begin{array}{l}9.1-12 \\
\text { number /ha }\end{array}$ & 3 & & $\begin{array}{c}15-7 \\
\text { number } \\
/ \text { ha }\end{array}$ & 3 \\
\hline & $\begin{array}{l}12.1 \quad-\quad+ \\
\text { number /ha }\end{array}$ & 1 & & $\begin{array}{c}7 \text { - } 0 \\
\text { number } \\
\text { /ha }\end{array}$ & 1 \\
\hline \multirow{5}{*}{$\begin{array}{c}\text { Household } \\
\text { income level }\end{array}$} & $+-616 \$$ & 10 & \multirow[b]{2}{*}{ Zoningstatus } & Available & 10 \\
\hline & $615-541 \$$ & 7 & & $\begin{array}{c}\text { Not } \\
\text { available }\end{array}$ & 1 \\
\hline & $540-461 \$$ & 5 & \multirow[b]{2}{*}{ Health unit } & Available & 10 \\
\hline & $460-386 \$$ & 3 & & $\begin{array}{c}\text { Not } \\
\text { available }\end{array}$ & 1 \\
\hline & $385--\$$ & 1 & \multirow[b]{2}{*}{ Infrastructure } & Available & 10 \\
\hline & & & & $\begin{array}{c}\text { Not } \\
\text { available }\end{array}$ & 1 \\
\hline
\end{tabular}

Also, it has been focused on farmlands which lost their farming properties in urban sprawl and faced out-of-purpose use, in addition to these 8 factors, land use capability class factor was also taken into account. For each factor, the scoring indicated in table 3 and the weights in table 4 procured as a result of AHP analysis were multiplied to obtain a nominal value which was calculated for any spatial unit/quarter in sprawl areas. 
Table 4. The weight for urban land, farmland and urban sprawl by AHP

\begin{tabular}{|c|c|c|c|c|}
\hline & FACTORS & Farmland & $\begin{array}{l}\text { Urban } \\
\text { Sprawl }\end{array}$ & $\begin{array}{l}\text { Urban } \\
\text { Land }\end{array}$ \\
\hline 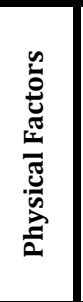 & $\begin{array}{l}\text { Soil Fertility (SF) } \\
\text { Shape of the Land (SL) } \\
\text { Land Use (LU) } \\
\text { Great Soil Group (GSG) } \\
\text { Land Use Capability Class (LUCC) } \\
\text { Elevation (E) } \\
\text { Aspect (A) } \\
\text { Erosion Degree (ED) } \\
\text { Crop Rotation System (CRS) }\end{array}$ & & $\begin{array}{l}0.0047 \\
0.0277 \\
0.0392 \\
0.0065 \\
0.0241 \\
0.0057 \\
0.0112 \\
0.0115 \\
0.0052\end{array}$ & $\begin{array}{l}0.0043 \\
0.0166 \\
0.0449 \\
0.0052 \\
0.0098 \\
0.0149 \\
0.0347 \\
0.0063 \\
0.0058\end{array}$ \\
\hline 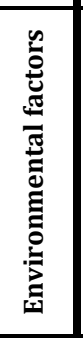 & $\begin{array}{l}\text { Proximity to Rural Settlement (PRS) } \\
\text { Proximity to City (PC) } \\
\text { Distance from Highway (DH) } \\
\text { Parcel Accessibility (PA) } \\
\text { Density Structure (DS) } \\
\text { Distance from Various Public Spaces (DPS) } \\
\text { Recreational Area (RA) } \\
\text { Infrastructure (I) } \\
\text { Commuting Time (CT) } \\
\text { Environ. Pollution (EP) }\end{array}$ & & & $\begin{array}{l}0.0154 \\
0.1176 \\
0.0937 \\
0.0241 \\
0.0199 \\
0.0393 \\
0.0389 \\
0.0423 \\
0.0615 \\
0.0181\end{array}$ \\
\hline 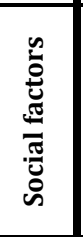 & $\begin{array}{l}\text { Population Density (PD) } \\
\text { Demographic Structure of Population (DSP) } \\
\text { Residential Space (RS) } \\
\text { Per Capita Education Unit (PE) } \\
\text { Per Capita Health Unit (PH) } \\
\text { Crime Rate (CR) } \\
\text { Cultural Community (CC) }\end{array}$ & & $\begin{array}{l}0.0266 \\
0.0213 \\
\mathbf{0 . 0 4 8 9} \\
\mathbf{0 . 0 4 6 8} \\
\mathbf{0 . 0 4 6 8} \\
0.0392 \\
0.0230 \\
\end{array}$ & $\begin{array}{l}0.0158 \\
0.0182 \\
0.0295 \\
0.0241 \\
0.0240 \\
0.0399 \\
0.0228\end{array}$ \\
\hline 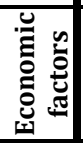 & $\begin{array}{l}\text { Agricultural Rent (AR) } \\
\text { Urban Rent (UR) } \\
\text { Tax (T) } \\
\text { Household Income Status (HIS) } \\
\end{array}$ & $\begin{array}{l}0.0832 \\
0.0088 \\
0.0062 \\
0.0100 \\
\end{array}$ & $\begin{array}{l}0.0056 \\
\mathbf{0 . 0 6 5 9} \\
0.0174 \\
\mathbf{0 . 0 4 2 9} \\
\end{array}$ & $\begin{array}{l}0.0065 \\
0.0893 \\
0.0196 \\
0.0199 \\
\end{array}$ \\
\hline 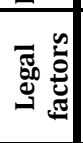 & $\begin{array}{l}\text { Ownership Status (OS) } \\
\text { Reconstruction (R) } \\
\text { Legal Restrict (Protected area, forest, } \\
\text { pasture etc.) (LR) }\end{array}$ & $\begin{array}{l}0.0536 \\
0.0854 \\
0.0135\end{array}$ & $\begin{array}{l}0.0233 \\
\mathbf{0 . 0 8 2 6}\end{array}$ & $\begin{array}{l}0.0145 \\
0.0291 \\
0.0337\end{array}$ \\
\hline
\end{tabular}

It is seen that the regions with the highest nominal value index (6 ${ }^{\text {th }}$ Region) are the quarters closest to city center. In areas approximate to city center, land value is higher and housing density is greater. These areas are more popular due to the low costs of commuting (Coisnon, Oueslati, \& Salanié, 2014b) and closeness of city center to the amenities. In quarters with highest index value urban rent is also higher, education, health and similar social amenities are closer and housing density is stronger. The fact that these areas are open to construction or in other terms urban zoning is also effective in receiving higher index values. The greater number of amenities accelerates the risk of transforming the lands from farm use to urban use (Bastian, McLeod, Germino, Reiners, \& Blasko, 2002). Within this context opening these $1^{\text {st }}$ class farmlands for urban use indicates an out-of-purpose use and clearly reveals the gaps in land use policies. As also reported in the study of (Du, Shi, \& Van Rompaey, 2013) this is indicative of the fact that due to the ineffective land use policies urban sprawling has gone out of control.

In value map some quarters located in the $5^{\text {th }}$ region, despite their proximity to city center, bear nominal value indexes lower than the $6^{\text {th }}$ region index, which might be related to the absence of 
health units and relative lowness of housing frequency and urban rent. In the $6^{\text {th }}$ region where nominal value index is the highest, small industries exist which boosts not only the urban rent in this region but also the density of housing. People employed in industrial sector, due to high costs of commuting; prefer to settle in locations close to industrial quarter, which in effect increases the density. In relevant literature it has been noted that the development of industry and commerce in regions closer to highways played role in the development of new settlements and formation of urban sprawl phenomenon (Patacchini, Zenou, Henderson, \& Epple, 2009; Polidoro et al., 2011). It is also stated that industrial and correspondingly housing sector shifted towards city outskirts to select low-value farmlands which in effect transformed farmlands into urban lands and created urban sprawling (Du et al., 2013; Malaque III \& Yokohari, 2007), as also been verified in current study.

In quarters specified as $4^{\text {th }}$ Region in Value Map nominal value index is comparatively lower than the $5^{\text {th }}$ and $6^{\text {th }}$ regions. The reasons are, as shown in the analyses, longer distance to city center and the lower income level of household. Parallel to these analyses, it has been verified that proximity to city factor is quite an important factor in the valuation of urban sprawl. People with lower household income prefer lower-cost houses which are mostly scattered far away from city center. In addition, the areas in which $3^{\text {rd }}$ and $4^{\text {th }}$ regions are located are within borders of rural land and there exists a population still engaged in farming ${ }^{1}$. As acknowledged, welfare level of rural people in Turkey is low. The fact that in the $3^{\text {rd }}$ and $4^{\text {th }}$ regions some quarters are still closed for construction is also effective in receiving low nominal value index. It is even claimed that due to these reasons there are still some lands bearing farmland properties, as shown in figure 4 .

Quarters specified as $1^{\text {st }}$ and $2^{\text {nd }}$ regions are away from city center, low housing density, limited educational and health units and notzoned for construction. Consequently, urban rent is low and indexes are similarly quite lower. Also since they possess $6^{\text {th }}$ and $7^{\text {th }}$ class farmlands they are in practice the most applicable lands for non-agricultural use. The reason why these quarters stand out as urban sprawl in the analyses is that there is some housing density, though low. The reason why these quarters are selected as settlements is their position nearby intercity highway. It can also be argued that recreation land in the $2^{\text {nd }}$ region and Konya Metropolitan Facilities in the $1^{\text {st }}$ region are also some of the factors that played role in the opening of this area for settlement purposes.
1 InFigure4, as the base, the satellite images of the region are shown and farmlands in the specific regions are shown in darker colours. 
Figure 4. Nominal value map for the study area

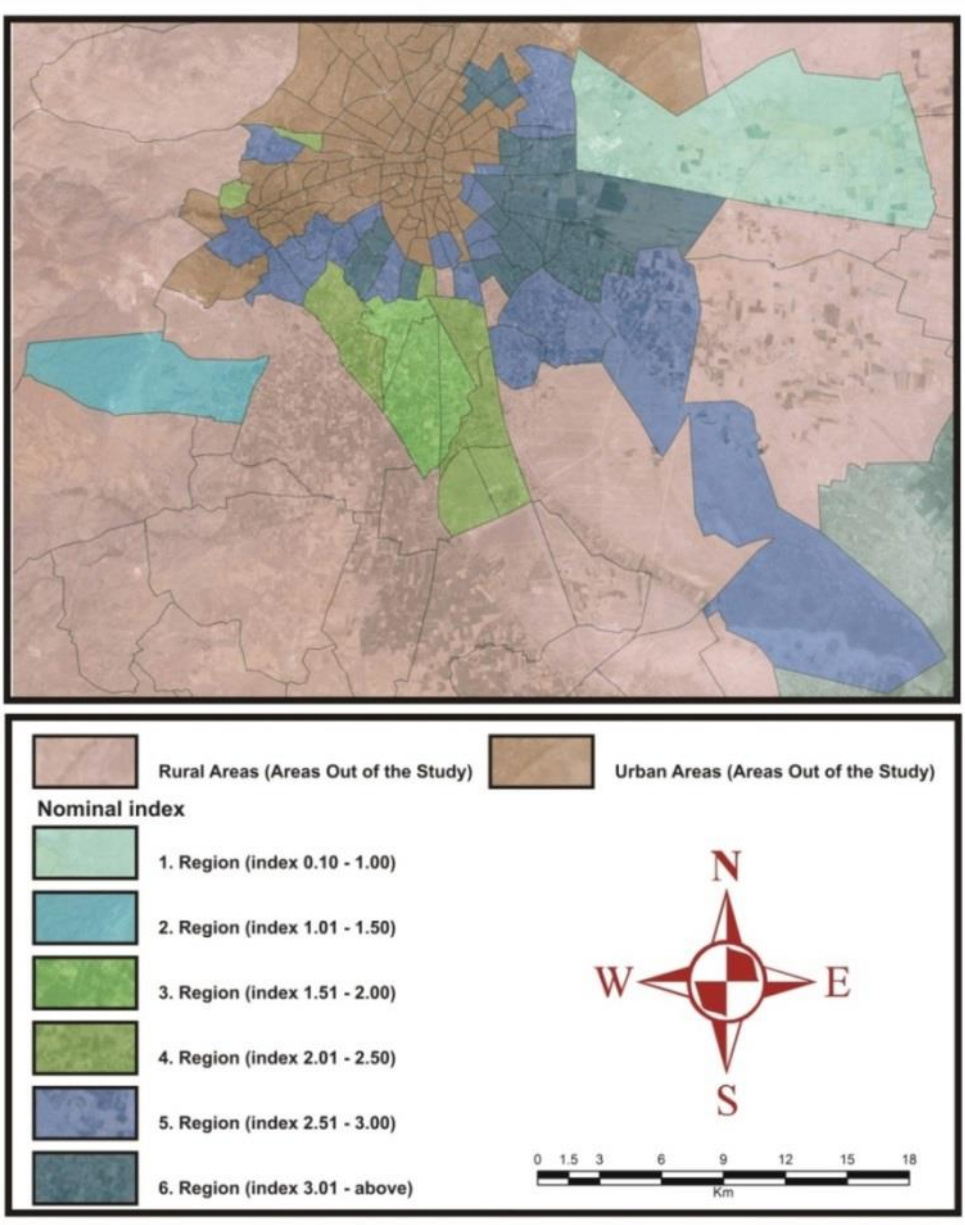

It is thus concluded that in the valuation of farmlands in urban sprawl, not agricultural criteria but urban criteria played more critical role. The reason is that farmlands in urban sprawls have lost their agricultural identity and turned into areas for nonagricultural purposes. The most important factors affecting the value of lands in urban sprawls are proximity to the city center, presence of social amenities and urban rent and these factors have been verified via value map obtained through nominal value calculations. This deduction also validates Hypothesis 2 .

\section{CONCLUSIONS}

Urban sprawls are transition zones with indefinite borders between urban and rural areas. In our study the borders of urban sprawl area in Konya city have been detected. For that purpose, the index that was developed via using urban sprawl-triggering factors was utilized. At the end of these analyses, within the scope of factors affecting urban sprawl, in addition to density and accessibility factors widely encountered in relevant literature, additional factors such as zoning status, constructing mobility and amenity factors also proved to be remarkably effective. Constructing mobility have emerged as a consequence of opening prime farmlands in study area to construction for urban use 
enabled urban growth while simultaneously triggered losing fertile farmlands.

Economic theory asserts that via Value $=$ Rent $/$ capitalization rate formula it is feasible to calculate the value of farmlands. Nonetheless as for the farmlands in urban sprawl, there exists no relation between the farm rent and market value because farmlands in urban sprawl transform into alternative uses with higher profits and lose their properties. Within that context, it was concluded in our study that urban sprawling quickened the transformation process in land use and urban sprawls are scattered forms of farmlands. In a different saying, it was detected that in research area farmlands in urban sprawls lost their properties and transformed into urban lands. Hence in the detection of the value of lands in these areas better results would be taken if evaluation was conducted on the factors affecting the value. It is also concluded that if the lands within urban sprawls were valued without considering the factors such as income and market value which are all traditional methods affecting the value, objective results would not be received hence there emerges the need to actualize relevant legal regulations.

The analyses also revealed that farm criteria have no effect on the lands in urban sprawl but rather urban criteria are more effective. It was also detected that the most effective factors on the value of lands in urban sprawls are proximity to the city center, urban rent and existence of social amenities. The popularity of these places for urban sprawl is because city center fails to meet the increasing housing need of risen population and lower price of farmlands. The reason why urban sprawl, a result of urban growth, violates fertile farmlands is related to implemented policies. To solve this problem; while on one hand specific policies are needed to fix rural population in their location, rural housing projects, integrated-farm development projects and farm development on the other hand land market-focused policies and reforms should be devised to ensure effective urban planning and compact development. It means that both urban and rural solutions should be improved in order to prevent the abuse of fertile farmlands that occurred as a result of urban sprawl.

In present research GIS technology has been utilized in the detection of urban sprawl borders as well as in the formation of the value maps of the lands in these areas. Adding a visual dimension to spatial factors affecting land value GIS technology provides geographical reference and critical data to infer the complexity of urban sprawl. This technology with no indeterminations and enabling quick generation of data has the qualities that would assist policy implementers. 


\section{ACKNOWLEDGEMENT}

This study was supported by The Scientific and Technological Research Council of Turkey.

\section{REFERENCES}

Adrian, J., \& Cannon, M. D. (1992). Market for agricultural land in the rural-urban fringe of Dothan, Alabama.

Akseki, H., \& Meşhur, M. Ç. (2013). Kentsel Yayılma Sonucu Yapılaşmaya Açılan Verimli Tarım Alanları: Konya Kenti Deneyimleri. Megaron, 8(3).

Angel, S., Parent, J., \& Civco, D. (2007). Urban sprawl metrics: an analysis of global urban expansion using GIS. Paper presented at the Proceedings of ASPRS 2007 Annual Conference, Tampa, Florida May.

Awasthi, M. K. (2009). Dynamics and resource use efficiency of agricultural land sales and rental market in India. Land use policy, 26(3), 736-743.

Bastian, C. T., McLeod, D. M., Germino, M. J., Reiners, W. A., \& Blasko, B. J. (2002). Environmental amenities and agricultural land values: a hedonic model using geographic information systems data. Ecological economics, 40(3), 337-349.

Bellver, J. A., \& Mellado, V. C. (2005). An application of the analytic hierarchy process method in farmland appraisal. Spanish Journal of Agricultural Research, 3(1), 17-24.

Bhatta, B. (2010). Analysis of urban growth and sprawl from remote sensing data: Springer Science \& Business Media.

Bhatta, B. (2012). Urban growth analysis and remote sensing: a case study of Kolkata, India 1980-2010: Springer Science \& Business Media.

Burton, E. (2000). The compact city: just or just compact? A preliminary analysis. Urban studies, 37(11), 1969-2006.

Cavailhes, J., \& Thomas, I. (2011). The influence of urban sprawl on farmland prices in Belgium (refereed paper). Paper presented at the ERSA conference papers.

Cavailhès, J., \& Wavresky, P. (2003). Urban influences on periurban farmland prices. European Review of Agricultural Economics, 30(3), 333-357.

Churchman, A. (1999). Disentangling the concept of density. Journal of planning literature, 13(4), 389-411.

Coisnon, T., Oueslati, W., \& Salanié, J. (2014a). Spatial targeting of agri-environmental policy and urban development. Ecological Economics, 101, 33-42.

Coisnon, T., Oueslati, W., \& Salanié, J. (2014b). Urban sprawl occurrence under spatially varying agricultural amenities. Regional Science and Urban Economics, 44, 38-49. 
Delbecq, B. A. (2010). Economic impacts of urban growth and urban sprawl on agriculture: A spatial analysis of land use change at the urban-rural fringe. Purdue University,

Din, A., Hoesli, M., \& Bender, A. (2001). Environmental variables and real estate prices. Urban studies, 38(11), 1989-2000.

Doğru, A. B. (2002). İstanbul kent çeperinde saçaklanma ve sürdürülebilirlik: eyüp kent çeperi örneği. Mimar Sinan Güzel Sanatlar Üniversitesi, Yüksek Lisans Tezi.

Du, S., Shi, P., \& Van Rompaey, A. (2013). The relationship between urban sprawl and farmland displacement in the Pearl River Delta, China. Land, 3(1), 34-51.

Estiri, H. (2012). Tracking urban sprawl: applying Moran's I technique in developing sprawl detection models. Emergent Placemaking, 47-53.

Ewing, R., \& Hamidi, S. Measuring urban sprawl and validating sprawl measures. National Institutes of Health and Smart Growth America; Washington, DC: 2014. In.

Ewing, R., \& Hamidi, S. (2014). Measuring urban sprawl and validating sprawl measures. Washington, DC: National Institutes of Health and Smart Growth America.

Ewing, R., Pendall, R., \& Chen, D. (2002). Measuring Sprawl and its Impact. Washington, DC, Smart Growth America. In.

Galster, G., Hanson, R., Ratcliffe, M. R., Wolman, H., Coleman, S., \& Freihage, J. (2001). Wrestling sprawl to the ground: defining and measuring an elusive concept. Housing policy debate, 12(4), 681-717.

Hasse, J. E., \& Lathrop, R. G. (2003). Land resource impact indicators of urban sprawl. Applied geography, 23(2-3), 159-175.

Hirt, S. (2007). Suburbanizing Sofia: Characteristics of postsocialist peri-urban change. Urban Geography, 28(8), 755780.

Jiang, F., Liu, S., Yuan, H., \& Zhang, Q. (2007). Measuring urban sprawl in Beijing with geo-spatial indices. Journal of Geographical Sciences, 17(4), 469-478.

Karakayacı, Z. (2018). Regression Analysis for the Factor Affecting on Farm Land/Urban Land Value in Urban Sprawl. Turkish Journal of Agriculture-Food Science and Technology, 6(10), 1357-1361.

Livanis, G., Moss, C. B., Breneman, V. E., \& Nehring, R. F. (2006). Urban sprawl and farmland prices. American Journal of Agricultural Economics, 88(4), 915-929.

Malaque III, I. R., \& Yokohari, M. (2007). Urbanization process and the changing agricultural landscape pattern in the urban fringe of Metro Manila, Philippines. Environment and Urbanization, 19(1), 191-206. 
Mills, E. S. (2003). Urban sprawl causes, consequences and policy responses: Gregory D. Squires, editor. Washington, DC: Urban Institute Press, 2002. Regional Science and Urban Economics, 33(2), 251-252.

Noor, N. M., \& Rosni, N. A. (2013). Determination of spatial factors in measuring urban sprawl in Kuantan using remote sensing and GIS. Procedia-Social and Behavioral Sciences, 85, 502-512.

Oueslati, W., Alvanides, S., \& Garrod, G. (2015). Determinants of urban sprawl in European cities. Urban Studies, 52(9), 1594-1614.

Patacchini, E., Zenou, Y., Henderson, J. V., \& Epple, D. (2009). Urban sprawl in Europe. Brookings-Wharton Papers on Urban Affairs, 125-149.

Polidoro, M., de Lollo, J. A., \& Barros, M. V. F. (2011). Environmental impacts of urban sprawl in Londrina, Paraná, Brazil. Journal of Urban and Environmental Engineering, 5(2), 73-83.

Polyzos, S., Minetos, D., \& Niavis, S. (2013). Driving factors and empirical analysis of urban sprawl in Greece. Theoretical and Empirical Researches in Urban Management, 8(1), 529.

Pucher, J., Peng, Z. r., Mittal, N., Zhu, Y., \& Korattyswaroopam, N. (2007). Urban transport trends and policies in China and India: impacts of rapid economic growth. Transport reviews, 27(4), 379-410.

Ready, R., \& Abdalla, C. (2003). GIS analysis of land use on the ruralurban fringe: The impact of land use and potential local disamenities on residential property values and on the location of residential development in Berks County, Pennsylvania: Northeast Regional Center for Rural Development, Pennsylvania State University.

Ready, R. C., \& Abdalla, C. W. (2005). The amenity and disamenity impacts of agriculture: estimates from a hedonic pricing model. American Journal of Agricultural Economics, 87(2), 314-326.

Slaev, A. D., \& Nikiforov, I. (2013). Factors of urban sprawl in Bulgaria. Spatium(29), 22-29.

Song, Y., \& Zenou, Y. (2006). Property tax and urban sprawl: Theory and implications for US cities. Journal of Urban Economics, 60(3), 519-534.

Sperandelli, D. I., Dupas, F. A., \& Dias Pons, N. A. (2013). Dynamics of urban sprawl, vacant land, and green spaces on the metropolitan fringe of São Paulo, Brazil. Journal of Urban Planning and Development, 139(4), 274-279. 
Sudhira, H., \& Ramachandra, T. (2007). Characterising urban sprawl from remote sensing data and using landscape metrics.

Terzi, F. (2010). Mekânsal Büyüme ve Konut Alanlarına Yönelik Gelişme Stratejileri. Fen Bilimleri Enstitüsü,

Thapa, R. B., \& Murayama, Y. (2008). Land evaluation for periurban agriculture using analytical hierarchical process and geographic information system techniques: A case study of Hanoi. Land use policy, 25(2), 225-239.

Torrens, P. (2008). A Toolkit for Measuring Sprawl. Applied Spatial Analysis and Policy, 1 (1), 5-36. In.

Torrens, P. M., \& Alberti, M. (2000). Measuring sprawl.

Turkstat. (2014). Turkish Statistical Institute. Retrieved from http://www.turkstat.gov.tr

Ventalo, W. L., \& Williams, M. R. (2001). Fundamentals of real estate appraisal (8 ed.). United States of America: Dearborn Real Estate Education.

$\mathrm{Wu}$, J. (2006). Environmental amenities, urban sprawl, and community characteristics. Journal of Environmental Economics and Management, 52(2), 527-547.

Zhao, P. (2011). Managing urban growth in a transforming China: Evidence from Beijing. Land Use Policy, 28(1), 96-109.

\section{Resume}

Zuhal Karakayacl; B.Arch, M.Sc., PhD. Received her B.Arch in Agricultural Economics from Ankara University, Faculty of Agriculture (2002) and her MSc. in Agricultural Economics from Selcuk University (2005). Earned her PhD. degree in Economics from Selcuk University (2011). Within the scope of TUBITAK scholarship, she continued her studies in Center for Rural Economy, Newcastle University in UK between 2013 and 2015. Currently works as an Assistant Professor at Selcuk University. Major research interests include agricultural management, land economics, urban sprawl and GIS.

Özer Karakayacı received his B.Arch and MSc. in City and Regional Planning from Selcuk University, Faculty of Agriculture (19962003). He earned his PhD. degree in Regional Planning from Yildiz Technical University (2011). He is currently working as an Assistant Professor at Selcuk University. Major research interests include regional planning, economic geography, social capital, industrial geography. 